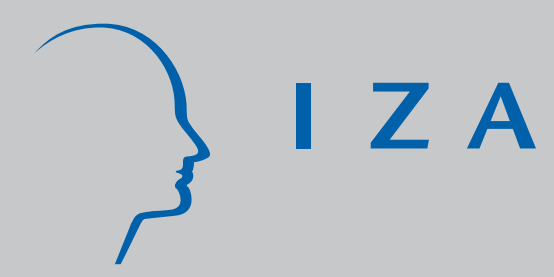

IZA DP No. 1071

The Effect of the Minimum

Wage on Prices in Brazil

Sara Lemos

March 2004 


\title{
The Effect of the Minimum Wage on Prices in Brazil
}

\author{
Sara Lemos \\ University of Leicester \\ and IZA Bonn
}

\section{Discussion Paper No. 1071 \\ March 2004}

\author{
IZA \\ P.O. Box 7240 \\ 53072 Bonn \\ Germany \\ Phone: +49-228-3894-0 \\ Fax: +49-228-3894-180 \\ Email: iza@iza.org
}

\begin{abstract}
Any opinions expressed here are those of the author(s) and not those of the institute. Research disseminated by IZA may include views on policy, but the institute itself takes no institutional policy positions.

The Institute for the Study of Labor (IZA) in Bonn is a local and virtual international research center and a place of communication between science, politics and business. IZA is an independent nonprofit company supported by Deutsche Post World Net. The center is associated with the University of Bonn and offers a stimulating research environment through its research networks, research support, and visitors and doctoral programs. IZA engages in (i) original and internationally competitive research in all fields of labor economics, (ii) development of policy concepts, and (iii) dissemination of research results and concepts to the interested public.
\end{abstract}

IZA Discussion Papers often represent preliminary work and are circulated to encourage discussion. Citation of such a paper should account for its provisional character. A revised version may be available on the IZA website (www.iza.org) or directly from the author. 


\section{ABSTRACT \\ The Effect of the Minimum Wage on Prices in Brazil}

There is very little empirical evidence on the effects of the minimum wage on prices in the international literature and none whatsoever for developing countries. This paper estimates the minimum wage price effect using monthly Brazilian household and firm data from 1982 to 2000 aggregated at a regional level. Empirical evidence on price effects will help to answer the question of who pays for the higher costs: firms, consumers or the unemployed. The answer to this question is a contribution to the controversial recent debate in the literature over the direction of the minimum wage employment effect. Employment might not be affected if firms are able to pass through to prices the higher labour costs associated to a minimum wage increase. In that case, consumers pay for the increase. Furthermore, if the poor consumers are those buying minimum wage labour intensive goods, or if these goods represent a large proportion of their consumption bundle, then minimum wage increases might hurt rather than aid the poor. Moreover, if minimum wage increases cause inflation, they will hurt the poor further, who disproportionately suffer from it. Robust results indicate that the minimum wage raises overall prices in Brazil. The resulting inflation is slightly higher for the poor than for the rich in the long run, smaller in low inflation periods, and larger in poorer regions.

JEL Classification: J38

Keywords: minimum wage, wage effect, employment effect, price effect, cost shock

Sara Lemos

Economics Department

University of Leicester

University Road

Leicester LE1 7RH

United Kingdom

Tel.: +44116252 2480

Fax: +44 1162522908

Email: sl129@leicester.ac.uk 


\section{INTRODUCTION}

This paper estimates the effects of minimum wage increases on prices using monthly Brazilian household and firm data from 1982 to 2000 aggregated at a regional level. Empirical evidence on price effects will help to answer the question of who pays for the higher costs associated to a minimum wage increase: firms, consumers or the unemployed. The answer to this question is a contribution to the controversial recent debate in the literature over the direction of the minimum wage employment effect. That is because employers respond to higher labour costs by reducing profits, reducing employment or raising prices:

Profits - There is very little empirical evidence to support the hypothesis that minimum wage increases are paid out of profits (Card and Krueger, 1995), but economic theory suggests this does not occur. Low wage firms are usually small firms in highly competitive markets and are not sufficiently profitable to absorb the extra costs. Even among larger and more profitable firms, capital is highly mobile and will flow to wherever profits are higher.

Employment - Most of the minimum wage literature has focused on employment effects, implicitly assuming that output prices are given, and that firms lower employment in response to minimum wage increases, as predicted by the standard neoclassical theory. This hypothesis, however, has been broadly dismissed in the empirical literature. In his survey, Brown $(1999, \mathrm{p} .2154)$ remarks: "the minimum-wage effect is small (and zero is often hard to reject)". Small employment effects, clustered around zero, are becoming prevalent in the literature (Freeman, 1994 and 1996; Brown, 1999). Evidence for Brazil is in line with the international literature (Lemos, 2003a; Carneiro, 2002; Corseuil and Servo, 2002).

Prices - Although there has been considerable effort to reconcile the standard theory prediction of employment decrease in presence of wage increases with the available empirical evidence (Card and Krueger, 1995; Brown, 1999), little attention has been paid to the theory prediction that an industry wide cost shock is passed on to prices. With employment and profits unaffected, higher prices are an obvious response to minimum wage increases. The assumption of constant prices is reasonable if firms that are affected compete with firms that are not affected by the increase, but unreasonable if the shock is industry wide. It is then important to assume that employment is given and that firms raise their prices in response to minimum wage increases. There is very little empirical evidence on this hypothesis in the international literature, and none whatsoever for developing countries. While there were over 300 studies on the employment effects by 1995 (Card and Krueger, 
1995), only 3 studies had been written on price effects by then for the US (Wessels, 1980; Katz and Krueger, 1992; Spriggs and Kelin, 1994), plus US Labour Department reports FLSA 1965 and 1969; MWSC, 1981).

The international literature mainly utilizes US data for the food sector - which employs a disproportionate share of minimum wage workers - implicitly assuming the overall prices given. Lemos (2004) surveys the available literature ${ }^{1}$ and concludes that, despite of different methodologies, data periods and data sources, most studies found that a $10 \%$ minimum wage increase raises food prices by about $4 \%$ and overall prices by about $0.4 \%$. Brown $(1999$, p. 2150$)$ in his survey ${ }^{2}$ remarks, "the limited price data suggest that, if anything, prices rise after a minimum wage increase".

Both overall and sectoral price effects are small in the US because minimum wage increases are small and the percentage of minimum wage workers is also small. For example, according to Card and Krueger (1995), a 15\% minimum wage increase was predicted to raise the prices of (fast-food) restaurants by $2.2 \%$ for a labour's share in total cost of $30 \%$. A $15 \%$ increase in the price of a factor that is itself about $30 \%$ of costs, raises overall prices by little enough to be ignored. Perhaps because price effects are small in the US, little further research has been done. However, this evidence might not carry out to other developed and developing countries.

Larger price effects are expected in Brazil. Consider the 15\% nominal minimum wage average increase in the sample period. In Pernambuco, a poor region, $11 \%$ of workers earn one minimum wage. Assuming 30\% labour's share (for comparison purposes), overall prices are expected to increase by $0.5 \%$. If not only those at, but also those below the minimum wage have wage increases (33\% of workers), prices are expected to increase by $1.5 \%$. If finally not only those at and below, but also those earning $0.5,1,1.5,2,2.5$ and 3 times the minimum wage have wage increases (46\% of workers), prices are expected to increase by $2.1 \%$. For a rich region, Sao Paulo, these effects range from $0.2 \%$ to $1.8 \%$. These effects are ten times larger when the largest increase in the sample period $(150 \%)$ is considered. Such effects are large because of three reasons: the percentage of workers

\footnotetext{
${ }^{1}$ These include: Gramlich (1976), Falconer (1978), Gordon (1975, 1980, 1981, 1982, 1988), Frye and Gordon (1981), Wessels (1980), Sellekaerts (1981), Oaxaca and Cox (1981), Wolf and Nadiri (1981), Katz and Krueger (1992), Card and Krueger (1995), Spriggs and Klein (1994), Wilson (1998), Lee and O'Roark (1999), MacDonald and Aaronson (2002), Aaronson (2001), Aaronson et al. (2003), MaCurdy and O’Brien-Strain (1997 and 2000), O’Brien-Strain (1999), O’BrienStrain and MaCurdy (2000), MaCurdy and McIntyre (2001) and Machin et al. (2003).

${ }^{2}$ Where only Wessels (1980), Katz and Krueger (1992) and Card and Krueger (1995) are reviewed.
} 
affected is large; minimum wage increases are large and frequent; and the indexer and numeraire roles that the minimum wage plays in Brazil.

Further to contributing to the minimum wage debate, answering the question of who pays for the increase is an important contribution for welfare analysis (Freeman, 1996). Absent profits and employment losses, the minimum wage is an anti-poverty program that transfers money from one group to another. The effectiveness of this program is a question of redistribution. If the poor are the consumers of minimum wage labour intensive goods, or if these goods represent a large share of their consumption bundle, then minimum wage increases might hurt the poor. Moreover, if such increases cause inflation, they might hurt rather than aid the poor, who disproportionately suffer from it. This is particularly so in the presence of hyperinflation, as in Brazil. Extending the understanding of minimum wage effects both on prices and in developing countries is crucial if the minimum wage is to be used as a policy to help poor people in poor countries.

Robust results indicate that the minimum wage significantly raises overall prices in Brazil. The resulting inflation is slightly higher for the poor than for the rich in the long run, smaller in low inflation periods and larger in poorer regions. This paper is organized as follows. Section 2 presents the data. Section 3 provides the theoretical foundation for the empirical equation discussed in Section 4 (Section 4.1), which also discusses identification (Section 4.2), presents (Sections 4.3 and 4.4) and analyses the results (Section 4.5).

\section{DATA AND DESCRIPTIVE ANALYSIS}

\subsection{MINIMUM WAGE}

Regional minimum wages in Brazil existed since its introduction in 1940 until 1984, when it became national. Coverage has always been full; there are no differentiated minimum wage rates for specific demographic groups or labour market categories. ${ }^{3}$

Over time, the real minimum wage fell. This is because of its impact on both the inflation and the public deficit. First, after a steep decrease, the real minimum wage was adjusted and reached its peak during the $50 \mathrm{~s}$ boom. It then fell as a result of the subsequent recession. After the dictatorship installed in 1964 associated high inflation with wage adjustments, the real minimum wage was

\footnotetext{
${ }^{3}$ Accommodation and food costs can be deducted from the wage. That might account for some below minimum wage workers, although the majority of those are informal sector workers.
} 
systematically under-indexed. As a result, rational agents took increases in the minimum wage as a signal for price and wage bargains - even after law forbade its use as indexor and numeraire in 1987. Second, because minimum wage increases affect the public deficit - uncontrollably large and growing in the $80 \mathrm{~s}$ and $90 \mathrm{~s}$ via benefits, pensions, and the public sector wage bill - the fiscal impact was often a constraint to the size of the increase (Foguel et al. 2001).

If on the one hand holding constant the nominal minimum wage was used as a deflationary policy, on the other hand increases in the nominal minimum wage severely affected both prices and the public deficit and were therefore inflationary. This effect was perpetuated in a wage-price inflation spiral. Minimum wage indexation and reinforced inflationary expectations was a phenomenon first noticed by Gramlich (1976), Cox and Oaxaca (1981) and Wolf and Nadiri (1981); and more recently discussed by Card and Krueger (1995) and Freeman (1996). Maloney and Nunes (2003) show that the indexer and numeraire effects are a general phenomenon in Latin America.

Graph 1.a and 1.b show the nominal and real hourly minimum wage between 1982 and 2000. ${ }^{4}$ With the end of the dictatorship, nominal minimum wage adjustments were subject to the rules of five different stabilization plans. Plano Cruzado, in February of 1986, increased the minimum wage by $15 \%$ and introduced bi-annual adjustments, which would override should inflation be higher than $20 \%$. Nonetheless, the minimum wage was $25 \%$ lower in June of 1987 , when Plano Bresser was implemented. Wages were then frozen for 3 months and after that, they were indexed monthly by past inflation. Plano Verao, in January of 1989, again froze prices. From May of 1989, adjustments were made monthly; nonetheless, the minimum wage was 45\% lower by March of 1990, when Plano Collor was implemented. In September 1991, indexation was restricted to workers earning up to 3 times the minimum wage. In 1993 adjustments were bi-monthly and then monthly. In March of 1994, a daily indexer was introduced as a prelude for Plano Real in July of 1994, when the minimum wage decreased by $40 \%$ followed by a $42 \%$ increase in May of 1995 . Since then, it has been annually adjusted. The result of these indexation rules is the saw-toothed pattern in Graph 1.b, particularly remarkable within years of high inflation.

\footnotetext{
${ }^{4}$ Wages are set monthly in Brazil. The hourly minimum wage rate is obtained by dividing the monthly minimum wage by $44 \times 4.3$ after, and $48 \times 4.3$ until September of 1988, when the new Constitution shortened the working week. The hourly wage rate is obtained by dividing monthly earnings by 4.3 times the number of hours worked weekly.
} 


\subsection{PRICE}

The price data is the National Consumers Price Index (INPC), the National Wide Consumer Price Index (IPCA) and the Necessary Minimum Wage (SMN), all of which disaggregated by region. The choice of the price measure is very important in a high inflationary environment such as the one experienced in Brazil in the last 30 years. INPC (IPCA) is computed over the consumption bundle of households earning between 1 and 8 (1 and 40) minimum wages (Gonzaga and Machado, 2002); INPC puts more weight on goods consumed by poorer households. The correlation between the two is 0.99 both in levels and in differences. SMN is computed over the consumption bundle of households earning 1 minimum wage as defined in the Constitution, i.e., the subsistence income for an adult worker and his/her family. Even though such a bundle has been unaffordable at the prevalent minimum wage, this is the effective inflation experienced by a household with subsistence levels of consumption. The correlation between SMN and INPC/IPCA, is 0.99 (0.88) in levels (differences). Graph 1.c shows the three indices over time. SMN is largest during the whole sample period, but the pattern over time is similar for the three indices. The main price data is INPC; robustness checks using IPCA and SMN are performed (Section 4.4).

The raw correlation of price and the nominal minimum wage is 0.99 (0.55) in levels (differences). The pattern both in levels and in differences of the two is remarkably synchronized; this was also documented for the US (Aaronson, 2001). The other data is from PME (Monthly Employment Survey), PIM (Pesquisa Industrial Mensal), SONDA (Sondagem Industrial) and BACEN (Banco Central do Brasil). All data is available from the IBGE (Instituto Brasileiro de Geografia e Estatistica) and FGV (Fundacao Getulio Vargas).

\section{THEORETICAL GROUNDING}

The price effect studies available in the literature are grounded on the standard theory model prediction that if employers do not respond to changes in the minimum wage by reducing employment or profits, they respond by raising prices. However, none of them discusses explicitly the theoretical model that delivered their empirical equation specification (Lemos, 2004). This requires a more careful discussion.

Economic theory establishes various routes through which the minimum wage affects prices: (1) via labour demand, by pushing firm costs and prices upwards; (2) via labour supply, by increasing labour productivity, pushing prices downwards; or by increasing labour force participation, pushing 
wages (prices) downwards; (3) via aggregate supply, by decreasing employment and output, pushing wages and prices upwards; and (4) via aggregate demand, by increasing spending, pushing prices upwards; or by stopping those who became unemployed to spend, pushing prices downwards; or by decreasing the demand for (now more expensive) minimum-wage-labour-intensive-products, pushing prices downwards. All these routes, together with a rapidly changing economy, make it very difficult to isolate the price effects due to a minimum wage increase.

To account for all such routes, a simple standard general equilibrium model is constructed. The model consists of four equations (to solve for employment, wages, prices, and output). An alternative specification is then derived under imperfect competition, where the price equation is specified as a markup over cost. Both the general equilibrium reduced form equation and the imperfect competition profit maximizing equation are used to deliver the empirical equations estimated in Section 4.

General Equilibrium - Assume perfect competition in both the input and output markets, and a production function depending on labour and capital, $Y=f_{L K}(L, K)$, with input and output prices $W, r$, and $P$. Maximization of profits at the (representative) firm level delivers the aggregate unconditional demand for labour, $L^{d}=L(P, W, r)$, which can be re-written as $P=P_{l}\left(L^{d}, W, r\right)$. There is no sense in a price equation at the (price-taker) firm level, but at the industry level, the labour demand function is well defined. The minimum wage then affects prices through its effects on wages and on productivity. If the production function depends on capital and two types of labour (say skilled, paid $W$, and unskilled workers, paid $M W$ ), the minimum wage enters the equation directly, $P=P^{\prime}{ }_{1}\left(L^{d}, W, M W, r\right)$. This shows the relationship between aggregate prices and labour demand that follows from the firm behaviour. This equation might not be very informative, as it tells what happens to prices when the minimum wage changes, holding constant employment. However, it reflects the implicit assumption discussed in Section 1 that when holding employment constant, the minimum wage increase is passed on to prices. The specification estimated by Aaronson (2001) can be thought of as a labour demand curve.

If labour supply is assumed to depend on wages and prices, $L^{s}=L\left(P, W, L^{s}\right.$-shifters $)$, where $L^{s}$ shifters are supply shocks; and $L^{s}=L^{d}=L$ is used to eliminate $W$, the labour market equilibrium condition is $P=P_{2}\left(L, r, L^{s}\right.$-shifters $)$. The minimum wage can be included among the supply shocks or, as above, enter the equation directly, $P=P_{2}^{\prime}\left(L, M W, r, L^{s}\right.$-shifters $)$. This equation tells what happens to prices when the minimum wage changes, accounting for the response of both firms and workers, holding constant other input prices, employment and labour supply factors. 
If now the production function $Y$ is used to substitute out $L$, the aggregate supply equation is $P=P_{3}\left(Y^{s}, r, K, L^{s}\right.$-shifters $)$ or $P=P_{3}^{\prime}\left(Y^{s}, M W, r, K, L^{S}\right.$-shifters $)$. Subtracting and dividing both sides by lagged price delivers the Phillips curve. This equation summarizes the possible combinations of price and output that equilibrates the labour market. Once more, it might not be very informative, as it tells what happens to prices when the minimum wage changes, holding output constant

Most people will adjust their spending in response to higher prices. This determines whether and where jobs are lost and output is cut in the longer-run. The relationship between prices and the minimum wage needs to account not only for aggregate supply but also for aggregate demand effects. If $Y^{d}=Y^{s}=Y$ is used, where $Y^{d}=f\left(P, Y^{d}\right.$-shifters $)$, and $Y^{d}$-shifters are demand shocks; the economy equilibrium condition is $P=P_{4}\left(r, K, L^{s}\right.$-shifters, $Y^{d}$-shifters $)$ or $P=P_{4}^{\prime}\left(M W, r, K, L^{s}\right.$-shifters, $Y^{d}$-shifters $){ }^{5}$ This equation differs from previous ones because, in econometrics parlance, is a reduced form. It tells what happens to prices when the minimum wage changes, accounting for responses of firms, workers and consumers; i.e. it accounts for the interaction of all the above variables and their joint effect on prices. The (net) minimum wage coefficient is positive because the minimum wage increase contracts the economy and increases prices. The specifications estimated by Card and Krueger (1995), Sprigs and Klein (1994), Aaronson and Macdonald (2002) and Machin et al. (2003) can be thought of as reduced form equations.

Imperfect Competition - Assume a number of identical imperfectly competitive firms, each one of them with some market power; say that firms and consumers differ in their physical location and each firm has its own market area. If a demand and a cost relation are specified and the resulting profit maximizing condition is inverted, a price equation is obtained, where price is a markup over costs, $P=[e /(1+e)] c$, and $e$ is the price elasticity of demand. Note that the two main components of costs are labour productivity and wages (and the minimum wage affects both), which already accounted for in the first equation of the above general equilibrium model. Indeed, relaxing the price taking assumption does not change dramatically the above specifications - the cost function is the same for both monopolists and competitive firms - although it gives a different flavor to the interpretation of the results. The crucial difference here is that while for competitive markets, price is exogenous and the price equation is a standard labour demand function, for price-setter firms, the price equation reveals a relationship that must hold for profit maximization but it is not a labour

\footnotetext{
${ }^{5}$ One of the $Y^{d}$-shifters has to be a nominal variable (e.g. nominal Government expenditure or the money stock) to ensure that $Y^{d}(P)$ is homogeneous of degree zero (one) in nominal magnitudes.
} 
demand function, because prices are chosen jointly with employment. The minimum wage coefficient is expected to be positive: a minimum wage increase raises labour costs and prices of the entire industry.

\section{EMPIRICAL SPECIFICATION AND IDENTIFICATION}

The positive raw correlation between log nominal minimum wage and log price discussed in Section 2.2 needs to be proved robust when the effect of other variables (demand and supply shocks) on prices is controlled for. The particular choice of controls is given by theory (Section 3). Given that so little work has been done in this area, the approach of this paper is rather exploratory, aiming at a theoretically informed statistical investigation. The strategy here is to estimate various specifications grounded on the two models discussed in Section 3 in order to check the robustness of the minimum wage effect to alternative controls.

\subsection{EMPIRICAL EQUATION}

While empirical work on the price response to minimum wage increases is limited, there is a large empirical literature on the price response to changes in other industry wide costs, such as sales taxes and exchange rates. ${ }^{6}$ Because of this, the empirical equation delivered by the theoretical models in Section 3 will be discussed in the light of this so-called pass-through literature. This literature is primarily concerned with the burden of higher costs on consumers, and thus is well suited to study the extent to which higher labour costs associated to minimum wage increases are passed on to consumers. The primary objective is to measure whether $100 \%$ of the shock is passed through or not. This is estimated by a reduced form equation where price is explained by a cost shock and other controls (grounded on the imperfect competition model in Section 3).

Together with the pass-through literature, the aggregate supply and Phillips curve empirical literature (grounded on the general equilibrium model in Section 3) also provides guidance for the

\footnotetext{
${ }^{6}$ See Kotlikoff and Summers (1987) for a compendium on tax incidence and Poterba (1996) for a survey. Some authors found full pass-through (Poterba, 1996) and others, overshifting (Besley and Rosen, 1994) in contrast with partial passthrough in the earlier literature (Haig and Shoup, 1934). The literature on the impact of exchange rate movements on import and export prices (Goldberg and Knetter, 1997) usually finds partial pass-through (Gron and Swenson, 1996; Lee, 1997; Yang, 1997). As in the minimum wage price effects literature (Lemos, 2004), the sale taxes and exchange rate literature also used before-and-after, input-output and econometrics analysis.
} 
empirical price equations specification. Econometric explanation of inflation requires not only inertia and aggregate demand variables, but also supply shocks (e.g. oil price, exchange rate, productivity growth, etc.) and Government intervention or push-factors (e.g. minimum wage, social security taxes, employment protection, unions, etc.). ${ }^{7}$

Approximating the theoretical price equation by a logarithmic function and modelling time and regional fixed effects using dummies:

$$
P_{i t}=\bar{f}+\beta M W_{t}+\gamma W_{i t}+\delta r_{i t}+\varsigma C_{i t}+\lambda L_{i t}+\kappa K_{i t}+\mu Z_{i t}+f_{i}+f_{t}+v_{i t}
$$

where, for region i and time t: $P_{i t}$ is $\log$ prices; $M W_{t}$ is $\log$ nominal minimum wage; $W_{i t}$ is average of $\log$ nominal wages; $r_{i t}$ is nominal interest rate; $C_{i t}$ is average costs; $L_{i t}$ is employment rate (and hours worked); $K_{i t}$ is capital; $Z_{i t}$ is labour supply and aggregated demand shifters; $f_{i}$ is regional fixed effects; $f_{t}$ is time fixed effects; $\bar{f}$ is the intercept; and $v_{i t}$ is the error term. Labour supply shifters control for region specific demographics potentially correlated with the minimum wage, e.g. the proportion of workers in the population who are: young, younger than 10 years old, women, illiterates, retired, students, in the informal sector, in urban areas, in the public sector, in the building construction and in the metallurgic industry sector, basic education degree holders, high school degree holders and the proportion of workers with a second job. Aggregate demand shifters include consumption, Government expenditure, capital investment, imports, exports and taxes.

Several coefficients are in turn constrained to zero. The starting place is an ad hoc specification where $\bar{f}, \beta$, and $\lambda$ only are allowed to be nonzero. The empirical counterpart of the general equilibrium reduced form price equation is obtained if $\bar{f}, \beta, \delta, \kappa$, and $\mu$ are nonzero, and the imperfect competition profit maximizing equation, if $\bar{f}, \beta, \gamma$, and $\varsigma$ are nonzero. Each of these two equations was estimated assuming $Y=f_{L}(L)$ and $Y=f_{L K}(L, K)$. Assuming that labour is the only variable factor in the long run is equivalent to constraining the coefficients of capital and interest rate ( $\delta$ and $\kappa$ ) to be zero. Furthermore, static specifications are too restrictive. Assuming that the static specification is valid at each period, dynamics can be added to account for adjustment costs. This is because an increase in the minimum wage might not affect prices contemporaneously, but in future periods, as the inability to adjust other inputs instantaneously creates lagged responses in

\footnotetext{
${ }^{7}$ See Ball et al. (1988) and Goodfriend and King (1990) for surveys on prices and inflation modeling. For early work on the role of push factors, see Frye and Gordon (1981), Gordon (1982), and Layard and Nickell (1985 and 1986); for more
} 
prices. The effect of the minimum wage on prices over time is typically modeled by including lags of the minimum wage as regressors. The number of lags is an empirical matter (Section 4.3).

All models were estimated in first-differences, as it is usual in the literature. Dummies, past inflation, controls and the constant were included after differencing; regional dummies model region specific trends because regions are expected to grow at different rates. The constant is the base dummy. The models were White-corrected and sample size weighted, to account for the relative importance of each region (and for heteroskedasticity arising from aggregation). Serial correlation was assumed to vanish after differencing, adding dynamics, controls, regional and time dummies.

\subsection{IDENTIFICATION}

Most minimum wage price effect studies use the nominal minimum wage as their shock variable. However, the minimum wage is national in Brazil (Section 2.1) and full identification requires the shock variable to vary across regions. The typical minimum wage variable used in employment models is "Kaitz index" (Kaitz, 1970), defined as the ratio of the minimum wage to average wage adjusted for coverage of the legislation. Another minimum wage variable is "fraction affected", defined as the proportion of workers earning a wage between the old and the new minimum wage (Card, 1992). Card and Krueger (1995) and Spriggs and Klein (1994) used this variable in their price equations. A variable closely related to "fraction affected" is "fraction at" the minimum wage, defined as the proportion of workers earning one minimum wage (Dolado et al., 1996) (plus or minus $0.02 \%$, to account for rounding approximations).

Although the Kaitz index varies across regions and over time, the variation in average wages is what drives the variation in the ratio. As a result, the effect of the inverse of the average wages on prices is what would be ultimately estimated (Welch and Cunningham, 1978; Freeman, 1982). Brown (1999, p. 2130) advocates that the "degree of impact" measures (e.g., "fraction affected") are conceptually cleaner than the "relative minimum wage" variable (e.g., Kaitz index). He also notes that "fraction affected" is "not well-suited for papering periods when the minimum wage is constant, and so its impact should be declining. While there is more to be learned from a year in which the minimum wage increases by 10 or $15 \%$ more than average wages than from a year of modest decline, the periods between increases should together contain about as much information as the periods of increase." In other words, fraction is constant at zero regardless of how unimportant the minimum 
wage might become. "Fraction at" is conceptually related to "fraction affected" but does not suffer from the same drawback, as it can be defined even when the minimum wage is constant. Beyond statistical identification, "fraction at" is a measure of wage (price) inflation and thus well suited to study minimum wage price effects. Its correlation with the real minimum wage, the Kaitz index and "fraction affected" in the sample period is respectively $0.61,0.67$ and 0.10 .

Even though "fraction at" has regional variation, modeling time effects with interactions of month and year dummies would eliminate all the variation in the model. Each dummy would capture all that affects prices in each month - including discrete and systematic minimum wage increases and the associated variation in "fraction at". As a result, there would be no variation but noise left to identify the minimum wage effect. Because of that, time effects are modeled by year and month dummies but not their interaction; this controls for unobserved fixed effects across years and months (Burkhauser et al.; 2000). Also, stabilization plan dummies ${ }^{8}$ are included to capture common macro shocks under each stabilization plan.

\subsection{RESULTS}

To ensure identification, log nominal minimum wage in Equation (1) is replaced by "fraction at". Columns 1 and 2 of Table 1 show positive and significant estimates. The coefficient of "fraction at" in the ad hoc price model compares to the one in the wage model in Lemos (2003a). A 10\% increase in the minimum wage (increases "fraction at" by 0.3 percentage points and) ${ }^{9}$ increases prices by $0.15 \%$ and (average) wages by $0.08 \%$; the ratio between the two is 1.7 . Card and Krueger (1995) calculate this ratio (their minimum wage variable is "fraction affected") to be between 0.25 and 0.50 . The larger ratio here is a result of the indexer and numerarie roles played by the minimum wage in Brazil (Section 2.1).

The estimates are larger for models assuming $Y=f_{L}(L)$ and dynamics. Dynamics allowed the effect of "fraction at" on prices to take one year to be complete. Not all lagged minimum wage

\footnotetext{
8 Each had very particular rules (Abreu, 1992); macro shocks were similar within, and different across plans. Additionally, a dummy was defined in October 1988, when the new Constitution shortened the working week and introduced an and alternative shorter working day.

9 The 0.3 factor was obtained by regressing the difference of "fraction at" on the difference of the log of nominal minimum wage and controls associated to each empirical equation. Because the nominal minimum wage does not vary across regions in Brazil, the Kaitz index (using not only average wage, but also median wage, $25^{\text {th }}$ and $10^{\text {th }}$ percentile wage as the denominator) was also used. The 0.3 estimate was remarkably robust across specifications.
} 
coefficient estimates were individually significant, but they were jointly significant. These are long dynamics. Even though the rapid wage-price spiral in Brazil discussed in Section 2.1 suggests short dynamics, other factors such as the minimum wage indexer and numeraire roles, and long inflationary memory in Brazil might perpetuate the minimum wage effect on prices over time. ${ }^{10}$ Aaronson (2001) and Macdonald and Aaronson (2001) included lags and leads in their specifications and found that most of the prices response occurs in the two-month period immediately after a minimum wage increase, while the rest occurs in a two months window around this. They argue that the short dynamics is because the minimum wage changes do not generate the sort of coordination failure and stickiness in prices that other costs or demand shocks produce.

A $10 \%$ increase in the minimum wage raises prices by $0.08 \%-0.56 \%$ and $1.98 \%-3.07 \%$ in the short and long run across models, suggesting partial pass-through. The preferred specification is the one delivered by the general equilibrium equation assuming dynamics and the more complete production function, i.e., column 2, panel B, row 1 of Table 1 . This specification is more reliable conceptually and statistically: it is a reduced form equation; the effect of the shock variable on prices over time is accounted for through dynamics; adjustments in capital and other inputs in response to minimum wage increases are allowed for; and errors are expected to be serially uncorrelated. Using this specification, a $10 \%$ increase in the minimum wage raises prices by $0.32 \%$ and $2.38 \%$ in the short and long run. This result is robust when using the imperfect competition specification, and smaller than results using the less complete production function. This suggests that the estimates are sensitive to whether or not the interest rate is held constant but robust to whether or not perfect competition is assumed (Section 3). These results are sizeable for overall price effects; the existing literature reports less than $4 \%$ food sector price effect, and $0.4 \%$ overall price effects (Section 1 ).

Price effects across regions differ as regional consumption patterns differ. Regions that have a higher cost of living or that consume more carry more of the burden (MaCurdy and McIntyre, 2001). Increasing the minimum wage by $10 \%$ increases "fraction at" by $0.4(0.1)$ percentage points in $\mathrm{PE}$ (SP), a poor (rich) region, and increases prices by $0.42 \%(0.11 \%)$ in the short run and by $3.17 \%$

\footnotetext{
${ }^{10}$ Because of that, a finite number of lags might censor the adjustment process. A parsimonious way to allow for infinite number of lags is to include lagged price as a regressor. This captures any residual effect of the minimum wage on prices not captured by lags of the minimum wage explicitly. However, the lagged price coefficient was not significant and the "fraction at" coefficient was robust. Results were also robust to including 6,18 and 24 lags of "fraction at". Models allowing half a year dynamics severely censored dynamics; models allowing over a year dynamics produced nonsignificant higher lags coefficients.
} 
$(0.79 \%)$ in the long run using the preferred specification. In other words, it causes four times more inflation in PE than in SP.

\subsection{ROBUSTNESS CHECKS}

\subsubsection{Who Pays The Bill}

The evidence so far is supportive of the hypothesis discussed in the Section 1 that minimum wage increases are passed on to prices and are, therefore, born by consumers. Furthermore, this evidence suggests that overall prices increase and, therefore, all consumers - not just minimum wage labour intensive goods consumers - pay for the increase.

However, even in the presence of overall price effects, different consumers need not be affected in the same way. The implicit assumption in the literature is that the largest increase in prices following a minimum wage increase occurs in minimum wage labour intensive goods industries. This means that the consumers of such goods pay proportionately more for the increase. It has been suggested that these consumers are the low income (Freeman, 1996; Deere et al., 1996; O'BrienStrain and MaCurdy, 2000; MaCurdy and McIntyre, 2001). To test that, industry and consumption level data are required to identify what are such goods and who are their consumers. This would make it possible to define the typical low and high income consumption bundle and the respective income share spent on minimum wage labour intensive goods. This is what SMN, INPC and IPCA measure; i.e. the cost of the low, medium and high income typical consumption bundle and the implicit income share spent on minimum wage labour intensive goods. These indices can then be used to provide evidence on who pays for the increase. The relevant question here is whether the inflation caused by minimum wage increases affects the poor more severely.

Recall Graph 1.c that shows log of SMN, INPC and IPCA over time. SMN is largest during the whole sample period, suggesting that inflation was highest for the poor; the pattern over time is similar for the three indices, suggesting that all consumers were affected by the same inflation growth. If, in the absence of minimum wage increases, prices rose equally to all consumers, then the simple comparison of indices would be an estimate of the relative inflation experienced by the poor and the rich following a minimum wage increase. However, changes in prices might also be due to changes in other variables. Regression models were used to control for such variables. SMN and IPCA were used, in addition to INPC, to re-estimate the dynamic models specified in Section 4.2. The pass-through coefficient in these models measures the increase on the prices of goods consumed 
by the poor and the rich following a minimum wage increase. If this coefficient is the same in both equations, then the inflation caused by minimum wage increases is the same to poor and rich consumers. If, however, it is larger for low income consumers, then the poor are exposed to higher inflation following a minimum wage increase.

Columns 3 and 4 of Table 1 show positive and significant pass-through coefficient for low and high income consumers. A $10 \%$ increase in the minimum wage raises low (high) income consumers prices by $0.30 \%-0.42 \%(0.28 \%-0.55 \%)$ and $2.42 \%-2.91 \%(1.78 \%-2.88 \%)$ in the short and long run across models. Using the preferred specification (Section 4.3), a 10\% increase in the minimum wage raises prices by $0.30 \%(0.30 \%) \%$ and $2.56 \%(2.19 \%)$ in the short and long run. In other words, the inflation caused by the minimum wage is the same for low and high income consumers in the short run, but a little larger for low income in the long run. This suggests that, whoever the consumers of minimum wage labour intensive goods are (low or high income), they are affected roughly in the same way. Contrary to what is assumed in the literature, either low income consumers do not spend a much larger share of their incomes on minimum wage labour intensive goods, or the prices of such goods do not go up by much more, or both. Both explanations are at work for Brazil. Minimum wage workers are present in various sectors throughout the economy, thus the prices of a wide range of goods go up. Furthermore, the indexer and numeraire roles, and the spillover effects "propagate" the increase throughout the economy, increasing overall prices. As a result, consumers of all income levels (not only low income consumers) spend a substantial income share on goods whose prices went up (which are not only minimum wage labour intensive goods).

This is not to say that the effect of the minimum wage on prices across the income distribution is neutral. The poor undoubtedly suffer disproportionately more from any given inflation rate - which can be compared with a regressive sales tax (MaCurdy and McIntyre, 2001; O'Brien and MaCurdy, 2000). However, it is important to establish that in Brazil the poor are not exposed to a higher inflation rate immediately following a minimum wage increase - although they are exposed to a slightly higher inflation rate after a year of adjustments. MaCurdy and McIntyre (2001) find that when expressed as the income share of consumption, the extra costs in higher prices is slightly above $1 \%$ for families of all income groups in the US. 


\subsubsection{The Bill Is Smaller Under Low Inflation}

The dynamic models specified in Section 4.2 were re-estimated excluding the high inflation period prior to July of 1994 . Column 5 of Table 1 shows positive but not statistically significant estimates. The pass-through estimates across models reduced to $0.01 \%$ and $0.59 \%-0.72 \%$ in the short and long run. Using the preferred specification (Section 4.3), a 10\% increase in the minimum wage raises prices by $0.01 \%$ and $0.63 \%$ in the short and long run. The long run coefficient is now four times smaller than the one in Section 4.3, even though all models include time and region fixed effects to account for the unusually high inflation periods. The short run effect is now comparable with the $0.02 \%$ effect in the international literature reports (Section 1). Aaronson (2001) found evidence that the high inflation in the 1970s-1980s partially drives the pass-through coefficient in the US and Canada. Weiss (1993) argues that prices adjustments differ in countries that have experienced low and high inflation.

In summary, minimum wage increases significantly increase overall prices in Brazil. (1) The pass-through coefficient is larger in the long run when firms have had the chance to adjust to the higher costs and the effect of the minimum wage on prices is complete. (2) The pass-through coefficient is the same for low, medium and high income consumers in the short run, and slightly larger for lower income consumers in the long run, suggesting that the inflation caused by the minimum wage is roughly the same for the poor and the rich. (3) The pass-through coefficient is four times smaller in the long run under low inflation when firms are less able to adjust prices. (4) The pass-through coefficient is four times larger in a poor than in a rich region. These findings are robust to a number of specifications. They are in line with theory and with the international empirical literature. They are also in line with the hypothesis in the Brazilian literature that minimum wage increases are an important component of inflation (Section 2.1).

\subsection{RECONCILING WAGE AND EMPLOYMENT MINIMUM WAGE EFFECTS}

As discussed in Section 1, theory and empirical evidence on the minimum wage employment effects are at odds. On the one hand, standard economic theory unambiguously predicts that employment decreases in the presence of wage increases. On the other hand, although empirical evidence has established that minimum wage increases raise the wage of the poor, there is no consensus on whether this drives employment increases or decreases (Card and Krueger, 1995; 
Brown, 1999). The evidence for Brazil is in line with the international evidence: employment effects are small, not always negative and not always statistically significant, despite of sizeable wage effects (Lemos, 2003a; Carneiro, 2002; Corseuil and Servo, 2002).

The evidence in Sections 4.3 and 4.4 suggests partial pass-through effect of the minimum wage on prices. This evidence reconciles theory and empirical evidence. Evidence of sizeable wage and price effects, and small employment effects is consistent with an inelastic labour demand curve and a rapid wage-price spiral under high inflation (Section 2.1). This suggests that firms respond to minimum wage increases not by reducing production, but by raising prices. That is because firms do not incur in adjustment costs if they can pass through to prices the higher costs associated to minimum wage increases. Moreover, it suggests that firms are more able to increase prices when inflation is high. Cox and Oaxaca (1981) argue that the effects of a minimum wage increase depend on the accompanying monetary policy. An accommodating inflationary monetary policy offsets the disemployment effect of the minimum wage and increases prices.

\section{CONCLUSION}

There is very little evidence on the effects of the minimum wage on prices in the international literature and none whatsoever for developing countries. This paper estimates this effect using monthly Brazilian household and firm data for the 80s and 90s. Given that so little work has been done in this area, the approach is rather exploratory, aiming at a theoretically informed statistical investigation.

Robust results suggest that the minimum wage significantly increases overall prices in Brazil. A $10 \%$ increase in the minimum wage raises prices by $0.32 \%$ and $2.38 \%$ in the short and long run, suggesting partial pass-through. These are sizable in the context of the minimum wage literature, which reports less than $4 \%$ increase in the food sector prices, and $0.4 \%$ overall price effects. This is because of the high inflation environment in Brazil over the last decades, as well as the indexer and numeraire roles played by the minimum wage in this context. It is also because of large and frequent minimum wage increases, large spillover effects and the presence of minimum wage workers in industries other than the low wage. At a regional level, the minimum wage causes four times more inflation in a poor region than it does in a rich one.

Further to filling a gap in the existing literature, these findings are an important contribution for two reasons. On the one hand, they help to reconcile the controversial recent minimum wage debate 
of sizeable wage and small employment effects. Standard economic theory is not hurt if wage increases do not cause employment decrease but cause price increases. On the other hand, they help to answer the question of who is paying for the minimum wage increase. Minimum wage increases are passed on to prices and are, therefore, born by consumers. Furthermore, overall prices increase and, therefore, all consumers pay for the increase. The pass-through coefficient is roughly the same for low, medium and high income consumers in the short run, although slightly larger for lower income consumers in the long run. This is an important result because, contrary to what is assumed in the literature, either low income consumers do not spend a much larger share of their incomes on minimum wage labour intensive goods or the prices of such goods do not go up by much more, or both. In Brazil, because overall prices go up (not only prices of minimum wage labour intensive goods), consumers of all income levels (not only low income consumers) spend a substantial share of their income on goods whose prices went up.

Clearly the potential of the minimum wage to help the poor is bigger under low inflation. The minimum wage price effect is four times smaller in the long run when the high inflation period is excluded from the analysis. This, together with the evidence of clustered around zero employment effects, both in the international and Brazilian literature, suggests that the minimum wage has a concrete potential to help the poor under low inflation.

\section{REFERENCES}

AARONSON, D. (2001): "Price Pass-through and the Minimum Wage," Review of Economics and Statistics, 83, 158-169.

AARONSON, D., E. FRENCH, and J. MACDONALD (2003): "Product Market Evidence on the Employment Effects of the Minimum Wage," Unpublished Paper.

ABREU, M. (1992): A Ordem Do Progresso. Brazil: Campus.

BALL, L., N. G. MANKIW, and D. ROMER (1988): "The New Keynesian Economics and the Output-Inflation Trade-Off," Brookings Papers on Economic Activity, 1988, 1-65.

BESLEY, T. J., and H. S. ROSEN (1999): "Sales Taxes and Prices: An Empirical Analysis," National Tax Journal, 52, $157-178$.

BROWN, C. (1999): "Minimum Wages, Employment, and the Distribution of Income," in Handbook of Labor Economics, ed. by O. Ashenfelter, and D. Card. Amsterdam; New York and Oxford: Elsevier Science, North-Holland, 2101-2163.

BURKHAUSER, R. V., K. A. COUCH, and D. C. WITTENBURG (2000): "A Reassessment of the New Economics of the Minimum Wage Literature with Monthly Data from the Current Population Survey," Journal of Labor Economics, 18, 653-680. CARD, D. (1992): "Do Minimum Wages Reduce Employment? A Case Paper of California, 1987-89," Industrial and Labor Relations Review, 46, 38-54.

CARD, D. E., and A. B. KRUEGER (1995): Myth and Measurement: The New Economics of the Minimum Wage. Princeton: Princeton University Press.

CARNEIRO, F. G. (2002): "Uma Resenha Empirica Sobre Os Efeitos Do Salario Minimo No Mercado De Trabalho Brasileiro," 
Unpublished Paper.

CORSEUIL, C. H., and L. SERVO (2002): "Salario Minimo E Bem Estar Social No Brasil: Uma Resenha Da Literatura," Unpublished Paper.

COX, J., and R. OAXACA (1981): "Effects of Minimum Wage Policy on Inflation and on Output, Prices, Employment and Real Wage Rates by Industry," Report of the Minimum Wage Paper Commission, 6, 171-210.

DEERE, D., K. MURPHY, and F. WELCH (1996): "Examining the Evidence on Minimum Wages and Employment," in The Effects of the Minimum Wage on Employment, ed. by M. Kosters. Washington: AEI Press, 26-54.

DOLADO, J., and ET AL. (1996): "The Economic Impact of Minimum Wages in Europe," Economic Policy: A European Forum, 23, 317-357.

FLSA, Fair Labor Standard Act (1965): An Evaluation of the Minimum Wage and Maximum Hours Standards under the Fair Labor Standards Act. Washington: US Department of Labor.

- (1969): Minimum Wage and Maximum Hours Standards under the Fair Labor Standards Act. Washington: US Department of Labor.

FREEMAN, R. (1982): "Economic Determinants of Geographic and Individual Variation in the Labor Market Position of Young Persons," in The Youth Labor Market Problems: Its Nature, Causes and Consequences, ed. by R. Freeman, and D. Wise, 115148.

- (1994): "Minimum Wages--Again!," International Journal of Manpower, 15, 8-25.

— (1996): "The Minimum Wage as a Redistributive Tool," Economic Journal, 106, 639-649.

FOGUEL, M. N., L. RAMOS, and F. CARNEIRO (2001): "The Impacts of the Minimum Wage on the Labor Market, Poverty and Fiscal Budget in Brazil," Unpublished Paper.

FRYE, J., and R. J. GORDON (1981): "Government Intervention in the Inflation Process: The Econometrics of "Self-Inflicted Wounds"," American Economic Review, 71, 288-294.

GONZAGA, G., and D.C.MACHADO (2002): "Rendimentos E Precos," in Estatísticas Do Seculo Xx. Rio de Janeiro: IBGE Centro de Documentação e Disseminação de Informações.

GRAMLICH, E. M. (1976): "Impact of Minimum Wages on Other Wages, Employment, and Family Incomes," Brookings Papers on Economic Activity, 2, 409-451.

GOLDBERG, P. K., and M. M. KNETTER (1997): "Goods Prices and Exchange Rates: What Have We Learned?," Journal of Economic Literature, 35, 1243-1272.

GOODFRIEND, M., and R. G. KING (1997): "The New Neoclassical Synthesis and the Role of Monetary Policy," in Nber Macroeconomics Annual 1997, ed. by B. S. Bernanke, and J. J. Rotemberg. Cambridge and London: MIT Press, 231-283.

GORDON, R. (1982): "Inflation, Flexible Exchange Rates, and the Natural Rate of Unemployment," in "Workers, Jobs and Inflation", ed. by M. N. Baily. US: The Brookings Institution, 89-158.

GRON, A., and D. L. SWENSON (1996): "Incomplete Exchange-Rate Pass-through and Imperfect Competition: The Effect of Local Production," American Economic Review, 86, 71-76.

HAIG, R., and C. SHOUP (1934): The Sales Taxes in the American States. New York: Columbia University Press.

JACKMAN, R., R. LAYARD, and S. NICKELL (1996): "Structural Aspects of Oecd Unemployment," Unpublished Paper.

KAITZ, H. (1970): "Experience of the Past: The National Minimum, Youth Unemployment and Minimum Wages," US Bureau of Labor Statistics Bulletin, 1657, 30-54.

KATZ, L. F., and A. B. KRUEGER (1992): "The Effect of the Minimum Wage on the Fast-Food Industry," Industrial and Labor Relations Review, 46, 6-21. 
KOTLIKOFF, L., and L. SUMMERS (1987): "The Theory of Tax Incidence," in Handbook of Public Economics, ed. by A. Auerbach, and M. Feldstein. Amsterdam: North Holland.

LAYARD, P. R. G., and S. J. NICKELL (1985): "Unemployment, Real Wages, and Aggregate Demand in Europe, Japan and the United States," Carnegie Rochester Conference Series on Public Policy, 23, 143-202.

— (1986): "Unemployment in Britain," London School of Economics, Centre for Labour Economics Paper, 240.

LEE, J. (1997): "The Response of Exchange Rate Pass-through to Market Concentration in a Small Economy: The Evidence from Korea," Review of Economics and Statistics, 79, 142-145.

LEE, C., and B. O'ROARK (1999): "The Impact of Minimum Wage Increases on Food and Kindred Products Price: An Analysis of Price Pass-Through," US Department of Agriculture Technical Bulletin, 877.

LEMOS, S. (2003a): "Robust Quantification of Minimum Wage Effects On Wages And Employment Using a New Data Set - A Menu Of Minimum Wage Variables", UCL Working Paper.

— (2004): "The effect of the Minimum Wage on Prices", Unpublished Paper.

MACDONALD, J., and D. AARONSON (2002): "How Do Retail Prices React to Minimum Wage Increases?," Unpublished Paper.

MACURDY, T., and F. MCINTYRE (2001): "Winners and Losers of Federal and State Minimum Wages," Employment Policies Institute Foundation Paper, 6/01.

MACURDY, T., and M. O'BRIEN-STRAIN (1997): "Who Will Be Affected by Welfare Reform in California," Unpublished Paper.

— (2000): "Who Pays for Increases in the Minimum Wage: Distributional Effects Assuming Price Pass-Through," Unpublished Paper.

MACHIN, S., A. MANNING, and L. RAHMAN (2003): "Where the Minimum Wage Bites Hard: Introduction of Minimum Wages to a Low Wage Sector," Journal of The European Economic Association, Inaugural Issue, 154-180.

MALONEY, W., and J. MENDEZ (2003): "Minimum Wages in Latin America," Unpublished Paper.

MWSC, MINIMUM WAGE STUDY COMISSION (1981): Report of the Minimum Wage Study Commission. Washington: US Department of Labor.

O'BRIEN-STRAIN, M. (1999): "Distributional Effects of the Minimum Wage: Who Benefits and Who Pays for Increases in the Federal Minimum Wage 1996/97 and 1999/2000," Standford University.

O'BRIEN-STRAIN, M., and T. MACURDY (2000): "Increasing the Minimum Wage: California's Winners and Losers," Public Policy Institute of California Discussion Paper, 131.

POTERBA, J. M. (1996): "Retail Price Reactions to Changes in State and Local Sales Taxes," National Tax Journal, 49, 165-176.

RAMOS, L., and J. G. REIS (1993): "Quem Ganha Salario Minimo No Brasil?," Perspectivas da Economia Brasileira, 2, $491-511$.

STAIGER, D., and J. H. STOCK (1997): "Instrumental Variables Regression with Weak Instruments," Econometrica, 65, 557-586.

SELLEKAERTS, B. (1981): "Impact of Minimum Wage Legislation on Wage and Price Inflation," Report of the Minimum Wage Paper Commission, 6, 1-17.

SPRIGGS, W., and B. KLEIN (1994): "Raising the Floor - the Effects of the Minimum Wage on Low-Wage Workers," Unpublished Paper.

WEISS, Y. (1993): "Inflation and Price Adjustment: A Survey of Findings from Micro-Data," in Optimal Pricing, Inflation, and the Cost of Price Adjustment., ed. by E. Sheshinski, and Y. Weiss. Cambridge and London: MIT Press, 3-17.

WELCH, F. R., and J. CUNNINGHAM (1978): "Effects of Minimum Wages on the Level and Age Composition of Youth Employment," Review of Economics and Statistics, 60, 140-145.

WESSELS, W. (1980): Minimum Wages, Fringe Benefits and Working Conditions. Washington: American Enterprise Institute. WILSON, M. (1998): "Increasing the Mandated Minimum Wage: Who Pays the Price?," Unpublished Paper. 
WOLF, E., and M. NADIRI (1981): "A Simulation Model of the Effect of an Increase in the Minimum Wage on Employment, Output and the Price Level," Report of the Minimum Wage Paper Commission, 6, 217-232.

YANG, J. (1997): "Exchange Rate Pass-through in U.S. Manufacturing Industries," Review of Economics and Statistics, 79, 95-104. 


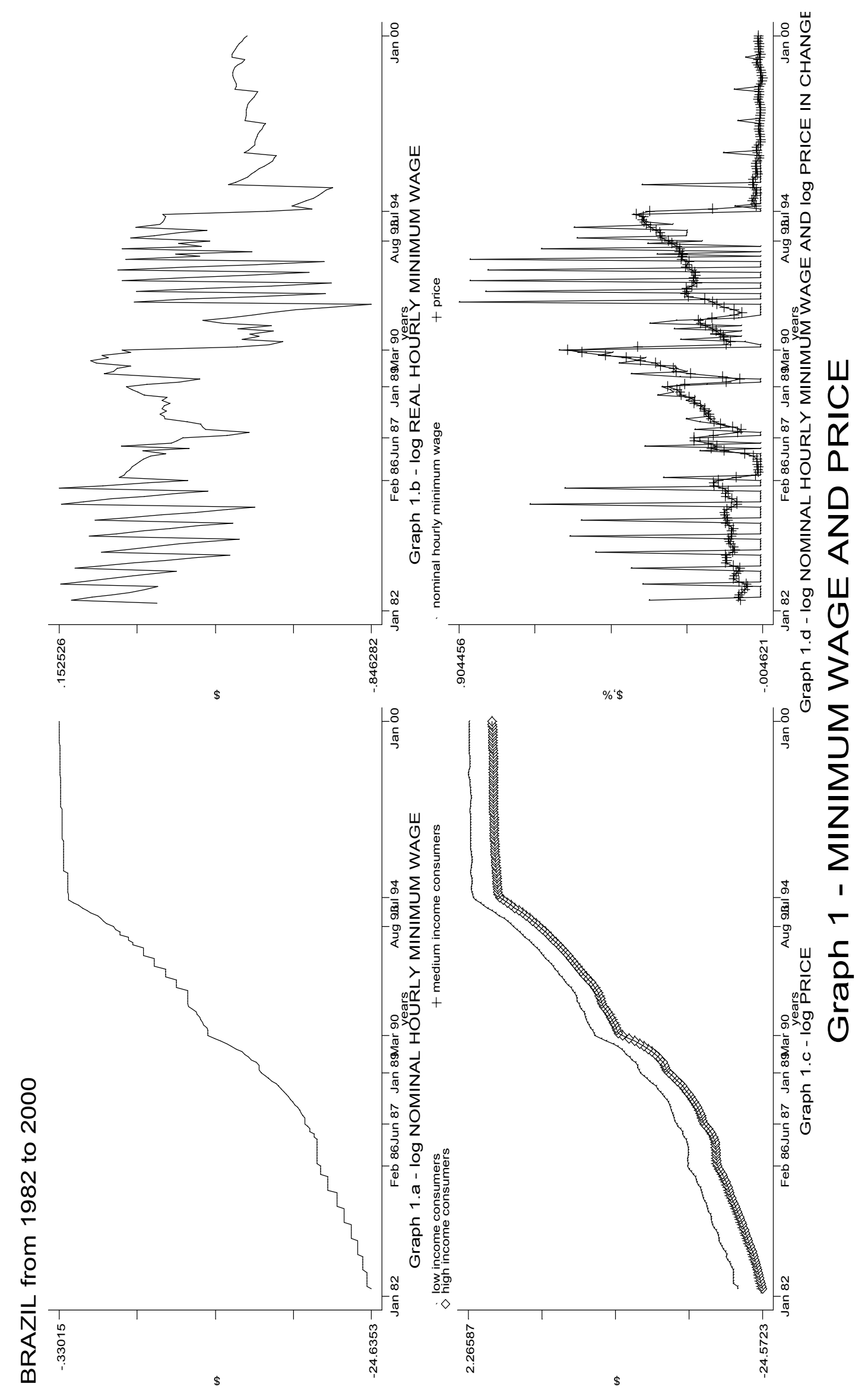




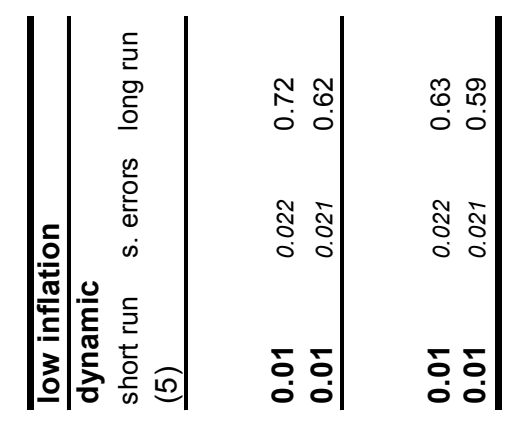

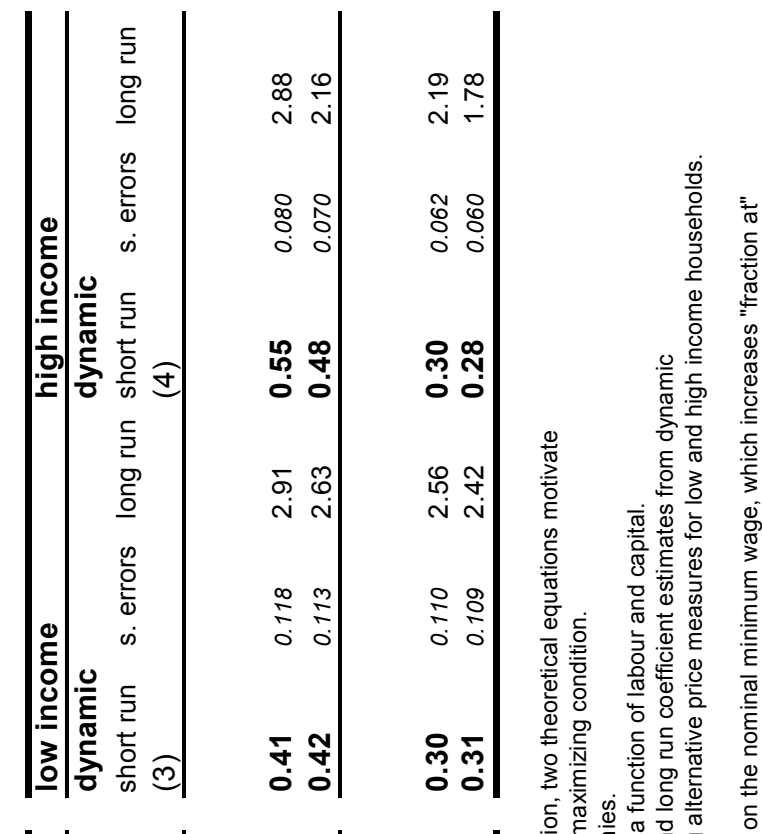

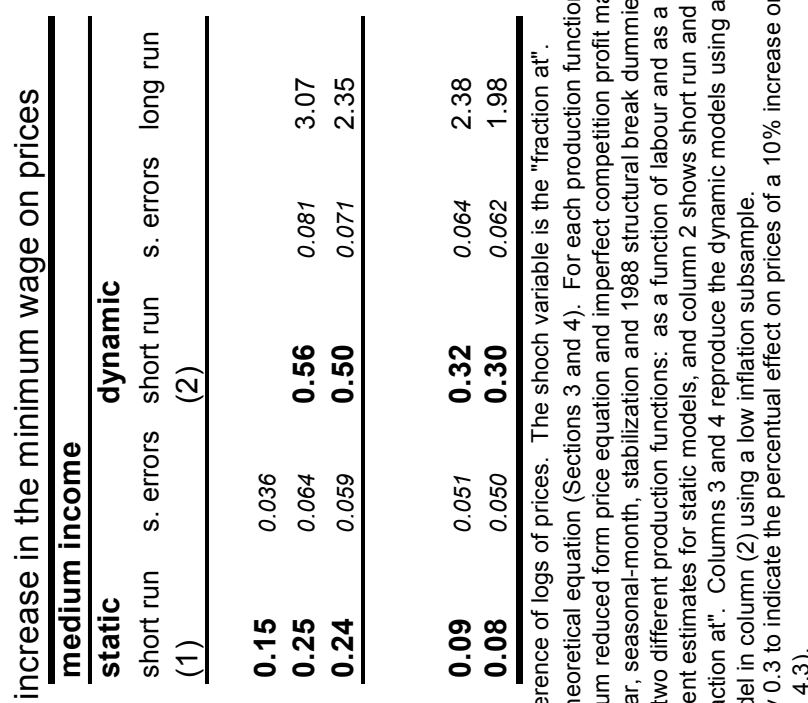

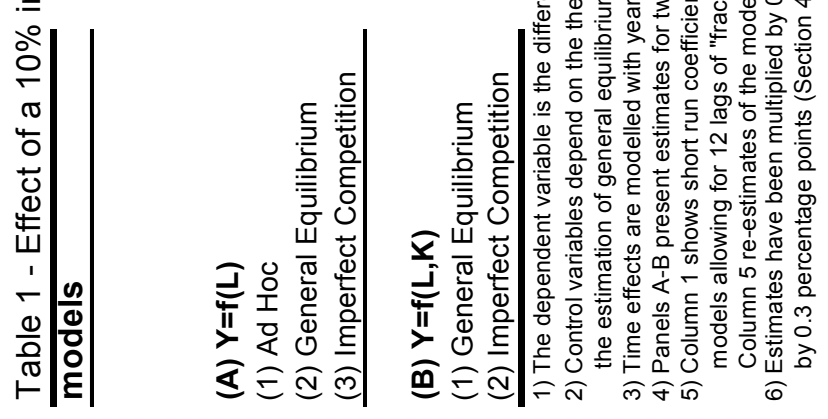

